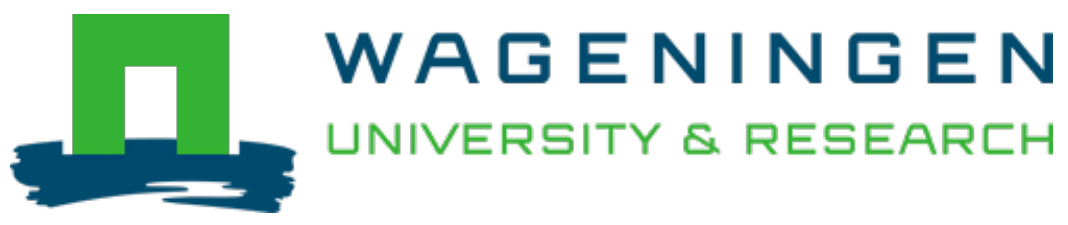

\title{
Effects of soaking, germination and fermentation on phytic acid, total and in vitro soluble zinc in brown rice
}

\author{
Food Chemistry \\ Liang, J.; Han, B.Z.; Nout, M.J.R.; Hamer, R.J. \\ https://doi.org/10.1016/j.foodchem.2008.02.064
}

This publication is made publicly available in the institutional repository of Wageningen University and Research, under the terms of article $25 \mathrm{fa}$ of the Dutch Copyright Act, also known as the Amendment Taverne. This has been done with explicit consent by the author.

Article 25 fa states that the author of a short scientific work funded either wholly or partially by Dutch public funds is entitled to make that work publicly available for no consideration following a reasonable period of time after the work was first published, provided that clear reference is made to the source of the first publication of the work.

This publication is distributed under The Association of Universities in the Netherlands (VSNU) 'Article $25 \mathrm{fa}$ implementation' project. In this project research outputs of researchers employed by Dutch Universities that comply with the legal requirements of Article $25 \mathrm{fa}$ of the Dutch Copyright Act are distributed online and free of cost or other barriers in institutional repositories. Research outputs are distributed six months after their first online publication in the original published version and with proper attribution to the source of the original publication.

You are permitted to download and use the publication for personal purposes. All rights remain with the author(s) and / or copyright owner(s) of this work. Any use of the publication or parts of it other than authorised under article $25 \mathrm{fa}$ of the Dutch Copyright act is prohibited. Wageningen University \& Research and the author(s) of this publication shall not be held responsible or liable for any damages resulting from your (re)use of this publication.

For questions regarding the public availability of this publication please contact openscience.library@wur.nl 


\title{
Effects of soaking, germination and fermentation on phytic acid, total and in vitro soluble zinc in brown rice
}

\author{
Jianfen Liang ${ }^{\mathrm{a}, \mathrm{b}, *}$, Bei-Zhong Han ${ }^{\mathrm{a}}$, M.J. Robert Nout ${ }^{\mathrm{b}}$, Robert J. Hamer ${ }^{\mathrm{b}}$ \\ ${ }^{a}$ College of Food Science and Nutritional Engineering, China Agricultural University, Beijing 100083, PR China \\ ${ }^{\mathrm{b}}$ Department of Agrotechnology and Food Sciences, Wageningen University, Wageningen, The Netherlands
}

Received 18 September 2007; received in revised form 3 January 2008; accepted 20 February 2008

\begin{abstract}
Rice is an important staple food in Asian countries. In rural areas it is also a major source of micronutrients. Unfortunately, the bioavailability of minerals, e.g. zinc from rice, is low because it is present as an insoluble complex with food components such as phytic acid. We investigated the effects of soaking, germination and fermentation with an aim to reduce the content of phytic acid, while maintaining sufficient levels of zinc, in the expectation of increasing its bioavailability. Fermentation treatments were most effective in decreasing phytic acid (56-96\% removal), followed by soaking at $10{ }^{\circ} \mathrm{C}$ after preheating $(42-59 \%)$. Steeping of intact kernels for $24 \mathrm{~h}$ at $25{ }^{\circ} \mathrm{C}$ had the least effect on phytic acid removal $(<20 \%)$. With increased germination periods at $30{ }^{\circ} \mathrm{C}$, phytic acid removal progressed from $4 \%$ to $60 \%$. Most wet processing procedures, except soaking after wet preheating, caused a loss of dry mass and zinc (1-20\%). In vitro solubility, as a percentage of total zinc in soaked rice, was significantly higher than in untreated brown rice while, in steeped brown rice, it was lower $(p<0.05)$. Fermentation and germination did not have significant effects on the solubility of zinc. The expected improvement due to lower phytic acid levels was not confirmed by increasing levels of in vitro soluble zinc. This may result from zinc complexation to other food components.
\end{abstract}

(C) 2008 Elsevier Ltd. All rights reserved.

Keywords: Soaking; Germination; Fermentation; In vitro solubility; Phytic acid; Zinc

\section{Introduction}

In developing countries, cereals and legumes are the main dietary sources of macronutrients (carbohydrate, protein), as well as micronutrients, such as iron, calcium and zinc (Lestienne, Besançon, Caporiccio, Lullien-Pellerin, \& Trèche, 2005; Lestienne, Icard-Vernière, Mouquet, Picq, \& Trèche, 2005; Lestienne, Mouquet-Rivier, IcardVernière, Rochette, \& Trèche, 2005). In China, plant foods provide at least $50 \%$ of the dietary energy and nutrients (Ma et al., 2005), and rice is the most important staple

\footnotetext{
${ }^{*}$ Corresponding author. Address: College of Food Science and Nutritional Engineering, China Agricultural University (East Campus), P.O. Box 294, Beijing 100083, PR China. Tel.: +86 10 62737699; fax: +86 10 62737078 .

E-mail address: liangj@@cau.edu.cn (J. Liang).
}

food. Unfortunately, rice is not a good source of metabolizable micronutrients, due to the presence of phytic acid. In plants, phytic acid is one of the main inhibitors of the availability of divalent cations such as $\mathrm{Fe}^{2+}, \mathrm{Ca}^{2+}, \mathrm{Mg}^{2+}$ and $\mathrm{Zn}^{2+}$. The phosphate groups of phytic acid (inositol hexakisphosphate) form stable complexes with such cations, thus preventing their bioavailability.

The bioavailability of minerals from foods is defined as the proportion of the minerals that can be absorbed and utilized within the body (Larsson, Minekus, \& Havenaar, 1997; Lestienne, Besançon et al., 2005; Lestienne, IcardVernière et al., 2005; Lestienne, Mouquet-Rivier et al., 2005). Solubility of minerals, $\mathrm{pH}$ of intestinal lumen, dietary factors and residence time at the absorption site influence the bioavailability of minerals (Larsson et al., 1997). The former could be predicted by molar ratios of phytic acid to minerals, $\mathrm{HCl}$ (hydrochloric acid)-extractability 
and in vitro solubility of minerals. Ma (2007) recently proposed that, when phytate and zinc are present in a molar ratio of 16:1, the zinc is no longer bioavailable. Typical ratios found for rice are: 4-15 and 61-74, for white and brown rice, respectively.

Since the health benefits of improving the bioavailability of minerals in rice are considerable, we have undertaken a systematic study consisting of three parts: (1) a screening of a wide range of rice varieties and growing conditions with respect to phytate and mineral contents, (2) a dry fractionation study aimed at identifying optimum conditions for removing phytate while retaining minerals and (3) a wet processing study with the same aim. The first study was published (Liang, Han, Han, Nout, \& Hamer, 2007) and reported a wide variation in both minerals and phytate. The optimum combination (highest mineral concentration and lowest phytate content) did not provide a significant increase in predicted mineral bioavailability. In the second study (Liang et al., accepted), it was found that milling leads to considerable losses of both phytic acid (minerals inhibitor) and minerals. Since, for example, iron and phytate are similarly distributed in the kernel, a dry fractionation would provide only limited opportunities for their separation. On the other hand, zinc is more evenly distributed in the kernel and could be separated from phytic acid. Wet processing provides a third technical option to improve the bioavailability of minerals. Such food processing methods, which can be used both on the industrial scale and in the household, appear to be promising to combat deficiencies of iron and zinc (Gibson et al., 2000). It was reported that wet processing (including soaking, germination and fermentation) leads to a reduction in phytic acid and increase of solubility of minerals in foods, and could thus improve bioavailability of minerals in cereals and legumes.

Soaking of millet, soya bean, maize, sorghum, and mung bean at $30^{\circ} \mathrm{C}$ for $24 \mathrm{~h}$ decreased the contents of phytic acid by $4-51 \%$ (Lestienne, Besançon et al., 2005; Lestienne, Icard-Vernière et al., 2005; Lestienne, Mouquet-Rivier et al., 2005), and soaking of sorghum flour ( $80 \%$ extraction) at room temperature for $24 \mathrm{~h}$ reduced phytic acid levels by 16-21\% (Mahgoub \& Elhag, 1998). Soaking of pounded maize for $1 \mathrm{~h}$ at room temperature already led to a reduction of phytic acid by $51 \%$ (Hotz, Gibson, \& Temple, 2001).
The use of moist conditions to stimulate germination is another technique for reducing phytate levels. Germination of sorghum for $4 \mathrm{~d}$ reduced phytic acid by $68-87 \%$ (Mahgoub \& Elhag, 1998). Badau reported that, with longer germination times, $\mathrm{HCl}$-extractability of calcium, iron and zinc in pearl millet was increased by $2-16 \%, 15-45 \%$ and 12-25\%, respectively (Badau, Nkama, \& Jideani, 2005).

Sourdough fermentation $\left(30^{\circ} \mathrm{C}\right.$ for $\left.4 \mathrm{~h}\right)$, led to a reduction of $60 \%$ of phytic acid in whole wheat flour with a $>30 \%$ increase of iron and zinc during in vivo absorption in rats (Lopez et al., 2003; Leenhardt, Levrat Verny, Chanliaud, \& Remesy, 2005). After $12 \mathrm{~h}$ of accelerated fermentation, $60 \%$ of phytic acid in sorghum was degraded (Mahgoub \& Elhag, 1998).

In summary, although a complete removal of phytic acid was not reported, wet processing technologies can help to reduce phytic acid so that solubility of minerals in foods could be increased. To our knowledge, there is little information in the literature on wet processing of rice.

Brown rice contains more minerals than does white rice. Compared to white rice, consumption of brown rice would increase the intakes of iron and zinc by factors of 3 and 1.7, respectively (Doesthale, Devara, Rao, \& Belavady, 1979; Kennedy, Burlingame, \& Nguyen, 2002; Heinemann, Fagundes, Pinto, Penteado, \& Lanfer-Marquez, 2005). We therefore selected brown rice for this study. The objectives of the present study were (1) to analyse the effects of wet processing (soaking, germination and accelerated lactic fermentation) on the mass balance and levels of minerals and phytic acid in brown rice and (2) to study the effect of phytic acid contents on the solubility of zinc in wet processed materials.

\section{Materials and methods}

\subsection{Materials}

Brown rice (Kenjian 90-31, cultivated in Heilongjing province and harvested in 2003) was collected from Beijing Huateng Model Rice Mill Company (Beijing, China).

\subsection{Soaking}

Brown rice was either heated as is, in a drying oven for 30 min at $100{ }^{\circ} \mathrm{C}$ (dry-preheated), or mixed with demineral-

Table 1

Preheating and soaking conditions

\begin{tabular}{|c|c|c|c|c|c|c|}
\hline \multirow[t]{2}{*}{ Treatment code } & \multicolumn{2}{|l|}{ Preheating } & \multicolumn{2}{|l|}{ Soaking medium } & \multicolumn{2}{|c|}{ Soaking time $(\mathrm{d})$} \\
\hline & Dry heated ${ }^{\mathrm{a}}$ & Wet heated ${ }^{\mathrm{b}}$ & Natural demineralized water (pH 5.9) & Acidic solution $^{\mathrm{c}}$ & 1 & 7 \\
\hline SDN & $\times$ & & $\times$ & & & $\times$ \\
\hline SWN & & $\times$ & $\times$ & & $x$ & \\
\hline SWA & & $\times$ & & $x$ & $x$ & \\
\hline
\end{tabular}

${ }^{\text {a }}$ Brown rice was heated in drying oven at $100{ }^{\circ} \mathrm{C}$ for 30 min before soaking.

${ }^{b}$ Mixture of brown rice and demineralized water $(1: 1, w / v)$ was heated in autoclave at $115^{\circ} \mathrm{C}$ for $10 \mathrm{~min}$.

${ }^{\mathrm{c}} \mathrm{pH}$ of mixture was adjusted to 3.5 with $5 \mathrm{~N} \mathrm{HCl}$ before soaking. 
ized water $(1: 1, \mathrm{w} / \mathrm{v})$ and autoclaved for $10 \mathrm{~min}$ at $115^{\circ} \mathrm{C}$ (wet-preheated). After this step, the rice was soaked at $10^{\circ} \mathrm{C}$ with demineralized water $(1: 5, \mathrm{w} / \mathrm{v})$. The mixture was either left as is, natural ( $\mathrm{pH} 5.9)$, or adjusted with $5 \mathrm{~N} \mathrm{HCl}$ to $\mathrm{pH}$ 3.5. Rice was soaked for either 1 (wet preheated samples) or 7 (dry heated samples) days. After soaking, the total mixture was centrifuged at $5000 \mathrm{~g}(10 \mathrm{~min})$. The pellet was freeze-dried and stored in sealed plastic bags at $4{ }^{\circ} \mathrm{C}$ for further analysis. Table 1 summarizes the different soaking conditions used. All soaking treatments were in duplicate.

\subsection{Steeping and sprouting}

Steeping and sprouting were carried out, following the procedure developed by Capanzana and Buckle (1997). For one separate small sample, approximately $30 \mathrm{~g}$ of brown rice were used. At the steeping phase, brown rice was soaked in $150 \mathrm{ml}$ of demineralized water in plastic boxes at $25^{\circ} \mathrm{C}$. Small samples were taken out from the incubator at intervals of 4, 8, 12 and $24 \mathrm{~h}$. After steeping for $24 \mathrm{~h}$, brown rice was separated by decanting and placed in plastic boxes and covered with punctured lids for sprouting for $72 \mathrm{~h}$ at $30^{\circ} \mathrm{C}$. Samples were taken at 12, 24, 36, 48 and $72 \mathrm{~h}$. Treatments of steeping and sprouting were in duplicate. After steeping and sprouting, samples were freeze-dried and stored in sealed plastic bags $4{ }^{\circ} \mathrm{C}$ for further analysis.

\subsection{Fermentation}

Mixtures of brown rice and demineralized water (ratio $1: 5, \mathrm{w} / \mathrm{v}$ ) were fermented naturally for $24 \mathrm{~h}$ at $30^{\circ} \mathrm{C}$. Starting on the second day and after each consecutive day, a fresh mixture was inoculated with $10 \%$ of the water of the previously fermented mixture, in order to obtain an accelerated fermentation by enrichment of acidifying microbiota (Nche, Odamtten, Nout, \& Rombouts, 1994).

All treatments were carried out in duplicate. After fermentation, samples were freeze-dried and stored in sealed plastic bags at $4{ }^{\circ} \mathrm{C}$ for further analysis.

\subsection{Zinc analysis}

\subsubsection{Total zinc content}

Rice samples were digested in microwave oven with hydrofluoric acid $(40 \%, \mathrm{w} / \mathrm{w})$ and concentrated nitric acid $(65 \%, w / w)$ to allow the analysis of total zinc. Zinc contents were analyzed using an inductively coupled plasma optical emission spectrometer (ICP-OES) (Elan 6000, PerkinElmer, Norwalk, CT). Each sample was digested in duplicate.

\subsubsection{In vitro soluble zinc content}

In vitro soluble zinc was defined as the relative amount of zinc that becomes soluble after enzymatic treatment. Rice samples were digested consecutively with enzymes, including amylase, pepsin, pancreatin and bile, under certain conditions following the enzymatic degradation procedure described by Kiers, Nout, and Rombouts (2000). Then, mixtures were centrifuged at $5000 \mathrm{~g}$ for $15 \mathrm{~min}$ at $4{ }^{\circ} \mathrm{C}$. The resulting supernatant was filtered $(0.45 \mu \mathrm{m}$ membrane, FP 030/3) and frozen until further analysis. Zinc levels were analyzed with ICP-OES. Each sample was enzymatically extracted in duplicate.

\subsection{Phytic acid}

A $100 \mathrm{mg}$ amount of sample (previously dried and ground) was placed in a glass tube and mixed with $10 \mathrm{ml}$ of $18.3 \mathrm{~g} \mathrm{dm}^{-3} \mathrm{HCl}$ containing $50 \mathrm{mg} \mathrm{dm}^{-3}$ cis-aconitate (internal standard). The mixture was boiled at $100^{\circ} \mathrm{C}$ for $15 \mathrm{~min}$ in a water-bath. Next, samples were transferred into $2 \mathrm{ml}$ Eppendorf tubes and centrifuged at 21,000 $\mathrm{g}$ for $10 \mathrm{~min}$. A $0.1 \mathrm{ml}$ volume of the supernatant was homogeneously mixed with $0.1 \mathrm{ml}$ of $18.3 \mathrm{~g} \mathrm{dm}^{-3} \mathrm{HCl}$ and $0.8 \mathrm{ml}$ of MilliQ water (Millipore, Billerica, MA, USA) and, from this mixture, $200 \mu \mathrm{l}$ were immediately transferred to HPLC phials.

Phytic acid was determined by high-performance liquid chromatography (HPLC) (Bentsink, Yuan, Koornneef, \& Vreugdenhil, 2003) using a Dionex (Sunnyvale, CA, USA) DX300, ICS2500 system with a suppressed conductivity detector range of $10 \mu \mathrm{S}$. An AS11 chromatographic column (Dionex) with a guard column was used. All analyses ( $20 \mu$ injection volume) were carried out at room temperature. The eluents (flow rate $1 \mathrm{ml} \mathrm{min}^{-1}$ ) used were as follows: 0-5min, $0.2 \mathrm{~g} \mathrm{dm}^{-3} \mathrm{NaOH}$; 5-15 min, linear gradient of $0.2-4 \mathrm{~g} \mathrm{dm}^{-3} \mathrm{NaOH} ; 15-20 \mathrm{~min}, 20 \mathrm{~g} \mathrm{dm}^{-3} \mathrm{NaOH}$; finally $20-35 \mathrm{~min}, 0.2 \mathrm{~g} \mathrm{dm}^{-3} \mathrm{NaOH}$.

\subsection{Statistical analysis}

Data were analyzed with SPSS 10.0 for windows. Significance was tested at a 5\% level using an independent-samples $t$-test.

\section{Results}

\subsection{Effect of wet processing on dry matter, phytic acid and zinc}

\subsubsection{General}

The various wet processing treatments were tested for their efficacy on decrease of phytic acid, while retaining micro- and macronutrients. Fig. 1 shows the different results obtained.

\subsubsection{Dry Matter}

Wet treatments led to a loss of dry matter of $7-16 \%$. Mass loss in accelerated fermented brown rice was $9-12 \%$. Soaking led to a higher mass loss than other treatments, especially soaking after wet preheating, with losses 


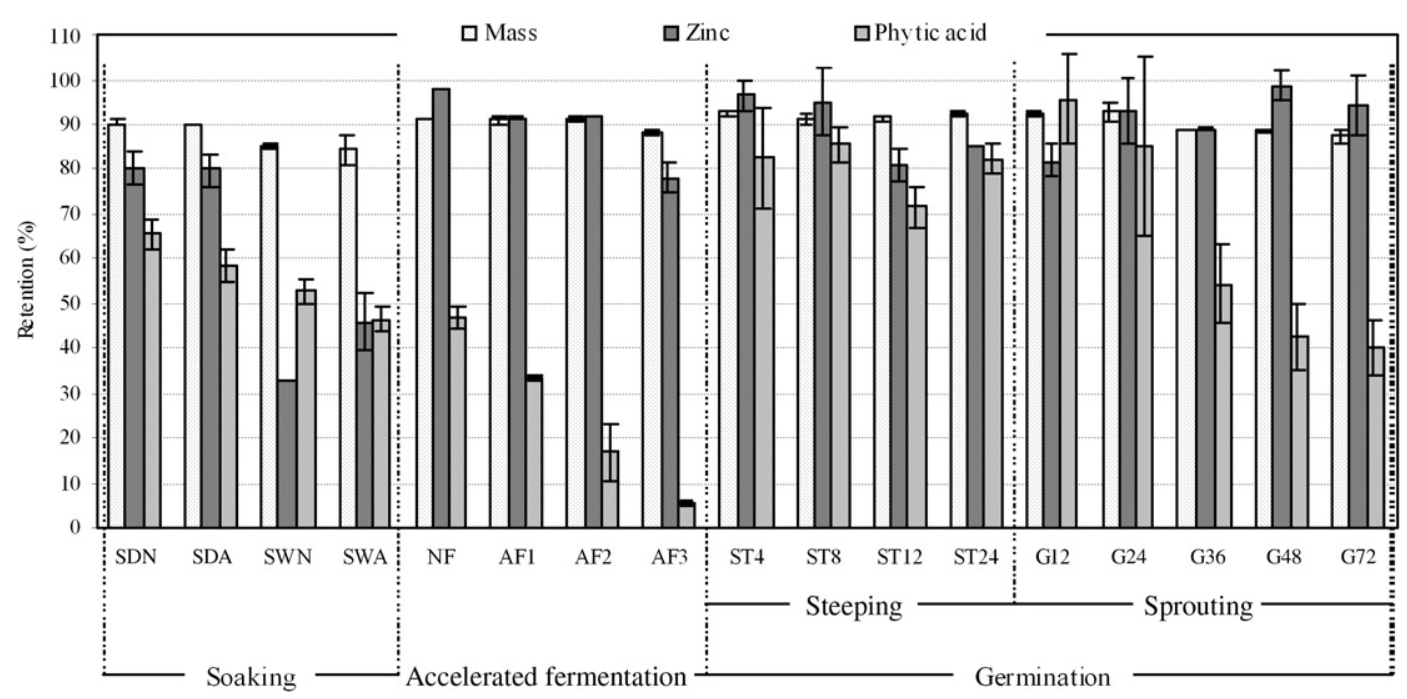

Fig. 1. Retention of mass, zinc and phytic acid in brown rice upon wet processing. Abbreviations: SDN, SDA, SWN, SWA: see Table 1; NF: natural fermentation without starters addition at $30^{\circ} \mathrm{C}$ for $24 \mathrm{~h}$; AF1/AF2/AF3: accelerated fermentation with one/two/three cycles of starter enrichment for $24 \mathrm{~h}$ and fermented at $30^{\circ} \mathrm{C}$ for $24 \mathrm{~h}$; ST4/ST8/ST12/ST24: brown rice was steeped for 4, 8, 12 and $24 \mathrm{~h}$, respectively; G12/G24/G36/G48/G72: brown rice was germinated for 12, 24, 36, 48 and $72 \mathrm{~h}$, respectively; Retention: Percentage of dry mass/zinc/phytic acid in certain quantities of brown rice after or before treatments.

up to $16 \%$. Mass loss during steeping and sprouting ranged from $7 \%$ to $13 \%$.

\subsubsection{Decrease of phytic acid}

Compared to untreated brown rice, wet processes (soaking, steeping and fermentation) significantly decreased phytic acid levels $(p<0.05)$. However, they varied in their ability to reduce phytic acid levels, which can be derived from the retention of phytic acid in samples (5-96\%). Fermentation was clearly the most effective: decreasing phytic acid by $53 \%$ up to $95 \%$. Steeping of intact grains, as a first step of germination, was not significantly effective: only a reduction of $14-28 \%$ was obtained. During fermentation, as well as germination, decrease of phytic acid progressed with time. No significant difference was observed between dry and wet preheating $(p<0.05)$.

\subsubsection{Retention of zinc}

Results also varied with the different wet processes applied. In general, zinc retention was between $80 \%$ and $99 \%$. Only wet preheating led to a considerable loss of zinc $(\sim 60 \%)$. In most wet treatments of brown rice, the retention of zinc was at similar levels as the retention of dry matter, which was in the range of $80-93 \%$. Rice soaked after wet preheating formed the exception, with dry matter retentions of $33 \%$ and $46 \%$, after soaking in demineralized water and acidic solutions, respectively. Retention of zinc in brown rice soaked after dry heating was about $80 \%$, which was much higher than after wet preheating.

\subsection{Contents of phytic acid and zinc in treated brown rice}

\subsubsection{General}

The relative losses of phytic acid, zinc and dry matter resulted in changes of absolute concentrations that are of nutritional relevance. Table 2 presents the concentrations of phytic acid and zinc in treated materials.

\subsubsection{Phytic acid}

Level of phytic acid in untreated brown rice was $12.5 \mathrm{mg} \mathrm{g}^{-1}$, while it ranged from 1 to $13 \mathrm{mg} \mathrm{g}^{-1}$ in treated samples. After soaking, the phytic acid was around 7$9 \mathrm{mg} \mathrm{g}^{-1}$ with wet preheated rice having lower levels than

Table 2

Effects of soaking, germination and fermentation on brown rice ${ }^{\mathrm{A}, \mathrm{E}}$

\begin{tabular}{llcl}
\hline Treatments & Methods $^{\mathrm{B}}$ & $\begin{array}{l}\text { Phytic acid }^{\mathrm{C}} \\
\left(\mathrm{mg} \mathrm{g}^{-1}\right)\end{array}$ & $\begin{array}{l}\text { Zinc }^{\mathrm{D}} \\
\left(\mathrm{mg} \mathrm{kg}^{-1}\right)\end{array}$ \\
\hline Untreated & None & $12.5 \pm 0.2$ & $19.6 \pm 1.4$ \\
Soaking & SDN & $9.1 \pm 0.5 \mathrm{a}$ & $16.5(15.7,17.2) \mathrm{a}$ \\
& SDA & $8.0 \pm 0.5 \mathrm{a}$ & $16.4(15.7,17.1) \mathrm{a}$ \\
& SWN & $7.7 \pm 0.4 \mathrm{a}$ & $7.1(7.1,7.1) \mathrm{b}$ \\
& SWA & $6.9 \pm 0.4 \mathrm{a}$ & $10.0(8.6,11.4) \mathrm{b}$ \\
Natural and & NF & $6.4 \pm 0.3 \mathrm{a}$ & $19.9(19.9,19.9) \mathrm{a}$ \\
accelerated & AF1 & $4.5 \pm 0.1 \mathrm{~b}$ & $18.5(18.5,18.6) \mathrm{a}$ \\
fermentation & AF2 & $2.3 \pm 0.9 \mathrm{c}$ & $18.6(18.6,18.6) \mathrm{a}$ \\
& AF3 & $0.7 \pm 0.1 \mathrm{c}$ & $16.4(15.7,17.1) \mathrm{b}$ \\
Germination: & ST4 & $11.1 \pm 1.5 \mathrm{a}$ & $19.3(18.6,19.9) \mathrm{a}$ \\
(1) steeping & ST8 & $11.7 \pm 0.5 \mathrm{a}$ & $19.3(15.7,22.9) \mathrm{a}$ \\
& ST12 & $9.7 \pm 0.6 \mathrm{a}$ & $16.4(15.7,17.1) \mathrm{a}$ \\
& ST24 & $8.4 \pm 0.5 \mathrm{a}$ & $17.1(17.1,17.1) \mathrm{a}$ \\
Germination: & G12 & $12.9 \pm 1.3 \mathrm{a}$ & $16.4(15.7,17.1) \mathrm{a}$ \\
(2) sprouting & G24 & $11.4 \pm 2.7 \mathrm{a}$ & $18.5(17.1,20.0) \mathrm{a}$ \\
& G36 & $7.6 \pm 1.2 \mathrm{~b}$ & $18.6(18.5,18.6) \mathrm{a}$ \\
& G48 & $6.0 \pm 1.0 \mathrm{~b}$ & $20.7(19.9,21.4) \mathrm{a}$ \\
& G72 & $5.7 \pm 0.9 \mathrm{~b}$ & $20.0(18.5,21.4) \mathrm{a}$ \\
\hline
\end{tabular}

\footnotetext{
A All data expressed on dry matter basis.

B Abbreviations of treatments are the same as in Fig. 1.

C Contents of zinc in untreated brown rice and contents of phytic acid in all materials: mean \pm standard deviation $(n=4)$.

D Contents of zinc: average of results of replicates of treatments (values of replicates).

${ }^{\mathrm{E}}$ Different characters mean significantly different at $p<0.05$.
} 
dry preheated. Rice fermented with enrichment starter (AF3) had the lowest phytic acid content $\left(0.7 \mathrm{mg} \mathrm{g}^{-1}\right)$, but natural fermentation (NF) also reduced the initial phytic acid level by $50 \%$. During germination, contents of phytic acid slightly decreased, from 11.7 to $8.4 \mathrm{mg} \mathrm{g}^{-1}$, during the steeping phase, and decreased further from 12.9 to $5.7 \mathrm{mg} \mathrm{g}^{-1}$ during sprouting over a period of $12-72 \mathrm{~h}$.

\subsubsection{Zinc}

The zinc level in initial brown rice was $19.6 \mathrm{mg} \mathrm{kg}^{-1}$. It ranged between 16 and $21 \mathrm{mg} \mathrm{kg}^{-1}$ in treated rice, except in brown rice soaked after wet heating, which contained less than $10 \mathrm{mg} \mathrm{kg}^{-1}$.

Further data analysis showed (Table 2) that duration of sprouting and enrichment starters in accelerated fermentation had significant effects on decrease of phytic acid. However, except for wet preheating and AF3, other wet processing did not have a significant effect on contents of zinc in final products $(p<0.05)$.

\subsection{Molar ratios of phytic acid to zinc ( $[P A] /[Z n])$ and in vitro solubility (IVS) of zinc}

The molar ratio of phytate to zinc is assumed to provide an indication of the bioavailability of zinc. In untreated brown rice, this ratio was 63 while, after processing, molar ratios of $[\mathrm{PA}] /[\mathrm{Zn}]$ varied from 4 to 107 . The lowest ratio was obtained by fermentation (AF3), and the highest in soaked rice after wet preheating. The amount of IVS-zinc

Table 3

In vitro solubility of zinc and molar ratios of phytic acid to zinc in treated materials

\begin{tabular}{llllc}
\hline Treatments & Methods $^{\mathrm{A}}$ & $\begin{array}{l}\text { In vitro soluble } \\
\text { zinc }\left(\mathrm{mg} \mathrm{kg}^{-1}\right)^{\mathrm{B}, \mathrm{C}}\end{array}$ & $\begin{array}{l}\text { Solubility } \\
(\%)^{\mathrm{D}}\end{array}$ & {$[\mathrm{PA}] /[\mathrm{Zn}]^{\mathrm{E}}$} \\
\hline Untreated & UR & $7.3 \pm 0.2$ & 37.5 & 62.8 \\
Soaking & SDN & $7.7(7.7,7.7) \mathrm{a}$ & 46.9 & 54.3 \\
& SDA & $6.7(4.1,9.3) \mathrm{a}$ & 40.9 & 48.0 \\
& SWN & $5.8(4.6,7.0) \mathrm{a}$ & 33.8 & 106.8 \\
Natural and & SWA & $5.7(5.3,6.0) \mathrm{b}$ & 56.8 & 68.0 \\
accelerated & AF1 & $6.0(3.4,8.6) \mathrm{a}$ & 30.2 & 31.7 \\
fermentation & AF2 & $7.8(6.8,6.9) \mathrm{a}$ & 36.8 & 24.0 \\
& AF3 & $4.1(3.3,9.6) \mathrm{a}$ & 40.0 & 12.2 \\
Germination: & ST4 & $5.4(4.9,6.0) \mathrm{a}$ & 24.8 & 4.2 \\
(1) steeping & ST8 & $5.5(4.7,6.3) \mathrm{a}$ & 28.2 & 56.6 \\
& ST12 & $4.6(3.3,5.9) \mathrm{a}$ & 28.0 & 59.7 \\
& ST24 & $6.6(5.0,8.1) \mathrm{a}$ & 38.4 & 48.3 \\
Germination: & G12 & $6.6(6.3,6.9) \mathrm{a}$ & 40.0 & 77.5 \\
(2) sprouting & G24 & $4.2(3.3,5.1) \mathrm{a}$ & 22.7 & 60.7 \\
& G36 & $6.2(5.7,6.6) \mathrm{a}$ & 33.1 & 40.2 \\
& G48 & $6.1(4.7,7.5) \mathrm{a}$ & 29.5 & 28.5 \\
& G72 & $8.3(8.2,8.3) \mathrm{b}$ & 41.3 & 28.1
\end{tabular}

\footnotetext{
A Abbreviations of treatments are the same as in Fig. 1.

${ }^{\text {B }}$ Contents of zinc: average of results of replicates of treatments (values of replicates).

${ }^{C}$ Different characters mean significantly different at $p<0.05$.

${ }^{\mathrm{D}}$ Expressed on dry matter basis.

E Calculated on total contents of phytic acid and zinc in treated materials.
}

of treated brown rice is assumed to provide an indication of the amount of zinc available for absorption in vivo. The IVS is expected to be more relevant than the phytate to zinc ratio, which is only based on contents. Untreated brown rice had $7.3 \mathrm{mg} \mathrm{kg}^{-1}$ of IVS-zinc and, after the various treatments, IVS zinc levels ranged from 4.2 to $8.3 \mathrm{mg} \mathrm{kg}^{-1}$ (Table 3).

\section{Discussion}

Given the important role of rice in the diet as a source of both macro- and micronutrients, an improvement of the bioavailability of zinc and iron is needed. Our studies indicated that selection of rice varieties (Liang et al., 2007), or optimization of dry processing (milling) showed limited promise for improvement of mineral availability. We therefore investigated the potential effect of wet processing. We aimed at identifying wet operations that could be used in combination with optimum growing and dry fractionation procedures. For the same reason, our analysis of the samples was limited to three main factors: phytate, zinc and dry matter. Other micronutrients, such as iron, are equally important but in this study we focussed on zinc.

Our results with wet processes, showing that they could significantly decrease phytic acid in brown rice, agree well with reports about similar treatments on other cereals, such as fermentation of white rice flour (Reddy \& Salunkhe, 1980 ), and steeping and sprouting of oats or corn (Fageer, Babiker, \& El Tinay, 2004; Larsson \& Sandberg, 1995). We found that soaking, germination and fermentation have different efficacies in reducing the content of phytic acid. Accelerated fermentation, especially fermentation with starters, enriched three times, is the most effective approach for reducing phytic acid in brown rice. In sorghum, soaking and natural fermentation had similar impacts on phytic acid (Mahgoub \& Elhag, 1998) which is in line with our results with NF. Decreases caused by fermentation and germination are mainly based on the action of enzymes while, in soaking, a combination of diffusion and enzymatic action is expected (Henderson \& Ankrah, 1985; Mahgoub \& Elhag, 1998). Other studies have proposed that the activity of endogenous phytase was the main factor leading to a reduction of phytic acid during soaking (Lestienne, Besançon et al., 2005; Lestienne, Icard-Vernière et al., 2005; Lestienne, Mouquet-Rivier et al., 2005). For brown rice, because of the presence of a tough and tight outer layer in the structure, which hinders the diffusion of substances, and low activity of endogenous phytase, which will be activated during steeping, decrease of phytic acid by soaking and steeping was limited. Furthermore, main factor(s) that cause the reduction of phytic acid in soaking and steeping, effect of phytase, or solubilization of phytate, or both, need further study. In a study by Carlson and Poulsen (2003) in which heated and non-heated barley and wheat were soaked, reduction of phytic acid was clearly higher in the non-heated treatment. Unfortunately, the heat treatment was not specified, so we cannot compare 
their results with ours. They ascribed the difference in phytate degradation to the inactivation of endogenous phytase. This again indicates the role of endogenous phytase. We did not obtain such differences between our untreated and preheated samples, which may be due to the use of different grains and a different extent of heat treatment; in any case, we found phytase activity in both untreated and preheated rice (data not shown). Our results demonstrate that the reduction of phytic acid increased with germination time, which agrees with previous studies reporting that the activity and/or production of phytase increased during steeping (Henderson \& Ankrah, 1985; Larsson \& Sandberg, 1995). We observed similar trends with fermentation. Abdalla, El Tinay, Mohamed, and Abdalla (1998) suggested that enzymatic hydrolysis of phytic acid by both endogenous phytase and microbial phytase (lactic acid bacteria can produce significant levels of phytase), and may account for most of the loss of phytic acid during fermentation (Abdalla et al., 1998; Leenhardt et al., 2005; Towo, Matuschek, \& Svanberg, 2006). Our observation of low phytic acid contents after fermentation is similar to results obtained with fermented whole wheat flour (Lestienne, Besançon et al., 2005; Lestienne, Icard-Vernière et al., 2005; Lestienne, Mouquet-Rivier et al., 2005). The results indicated that both endogenous phytase and microbial phytases contributed to a reduction of phytic acid in fermented brown rice. During accelerated fermentation, endogenous phytase was activated and accumulated and, at the same time, with growth of micro organisms, microbial phytase also accumulated. From Tables 2 and 4 we observed that longer duration of lower $\mathrm{pH}$ values also gave lower levels of phytic acid. From Table 4 we also observed that NF was much less effective for acidification and phytate removal than fermentation with cycle 3 starter (AF3). This could be due to a more rapid $\mathrm{pH}$ decrease and/or higher phytase activity, since optimal $\mathrm{pH}$ values for plant phytase and microbial phytase were about $5 \pm 0.5$ and $3 \pm 0.5$, respectively (Andriotis \& Ross, 2003). In addition to the influence of reaction conditions and ingredients used, factors such as enzymatic degradation, effect of $\mathrm{pH}$ on solubility and diffusion, could all be involved in the overall effect of the fermentation. Low starting $\mathrm{pH}$ (3.5) was not significantly affected by levels of phytic acid in SWN since the low $\mathrm{pH}$ was not maintained throughout the whole soaking period because of the buffering effect of components, such as protein, in brown rice.

Table 4

Initial and final $\mathrm{pH}$ values after natural, and accelerated fermentation of brown rice

\begin{tabular}{lll}
\hline Treatment & \\
\hline NF & Initial $\mathrm{pH}^{\mathrm{b}}$ & Final $\mathrm{pH}^{\mathrm{b}}$ \\
$\mathrm{AF} 1$ & $7.6(7.6,7.6)$ & $5.5(5.5,5.6)$ \\
$\mathrm{AF} 2$ & $6.6(6.5,6.6)$ & $5.3(5.2,5.4)$ \\
$\mathrm{AF} 3$ & $6.3(6.2,6.3)$ & $5.2(5.0,5.4)$ \\
\hline
\end{tabular}

a Abbreviations are the same as in Fig. 1.

b Average (values of replicates).
The retention and solubility of individual minerals were also affected by process conditions. For zinc, only soaking after wet processing resulted in significantly lower retention compared with the other treatments. This can be explained by the uniform distribution of zinc in the grain and the effect of wet preheating. Whereas dry preheating only results in minor physical damage, such as fissures (or cracks) in the kernels, wet preheating induced swelling of the kernel and gelatinization. The swollen kernel would allow better diffusion and we expect this to be the main reason for the higher loss of zinc and dry matter in soaked brown rice after wet preheating. In fermented brown rice, zinc losses ranged from $1 \%$ to $20 \%$.

We expected that, with lower molar ratios of $[\mathrm{PA}] /[\mathrm{Zn}]$, the in vitro solubility of zinc would increase, but this relation was not significant. This discrepancy was also observed by authors who studied other cereals, such as sorghum, millet and millet bran fractions (Lestienne, Besançon et al., 2005; Lestienne, Icard-Vernière et al., 2005; Lestienne, Mouquet-Rivier et al., 2005; Matuschek, Towo, \& Svanberg, 2001). Possibly, the molar ratio of $[\mathrm{PA}] /[\mathrm{Zn}]$ must be very low (possibly $<0.2$ ) to achieve increased zinc solubility. Theoretically, one mole of phytic acid could bind four moles of zinc. Under the conditions used, soaking, germination or fermentation are not able to completely eliminate phytic acid, so the residual phytate might still interfere with zinc solubility. Another explanation is that a prediction of solubility of minerals is not feasible by phytic acid to mineral ratios alone. For instance, it was reported that lower inositol phosphates (inositol mono-, bi-, tri- and tetraphosphates), produced during fermentation, increased the capacity of binding minerals of higher-phosphorylated inositol phosphates (IP6 and IP5: myo-inositol pentaphosphate), although they were present at a low level (Sandberg et al., 1999). In addition, all forms of zinc phosphate are poorly soluble. Similar to polyphenols in sorghum and millet (Matuschek et al., 2001; Towo et al., 2006), other matrix components that limit in vitro solubility, such as dietary fibre, can be present in brown rice. Little is known about the affinity of such components for minerals. Their inhibition might be even more effective than that of phytic acid. Clearly, these hypotheses need further study.

Another aspect that needs further attention is the validity of in vitro solubility of zinc as an indicator for in vivo bioavailability. Although it has been demonstrated that the addition of phytic acid to, e.g., white bread (Sandberg et al., 1993), results in a strong decrease of in vivo human zinc uptake, the situation for rice may be different, and more comprehensive data for solubility and in vivo uptake from food matrices are urgently needed.

From this study, we conclude that neither soaking, germination, nor fermentation significantly improve the apparent bioavailability of minerals in rice. It may be of interest to combine wet processing methods, including phytase treatment, with other approaches, such as the application of uptake enhancers, to improve the availability of 
minerals in rice. More research will be required to understand the effects of matrix components, and to explore opportunities for combined process approaches.

\section{Conclusion}

Soaking, germination and fermentation, led to varying decreases of phytic acid in brown rice. The most effective approach (AF3) could reduce $96 \%$ of total phytic acid and decrease the molar ratios of phytic acid to zinc below 5 . Wet processing (except soaking after wet heating) led to $1-20 \%$ of mass loss, and a similar loss of zinc as well.

The sharp decrease in ratio would suggest that fermentation especially would be a successful way to increase zinc bioavailability. However, results from in vitro solubility measurement of zinc showed little improvement over untreated brown rice. This could result from the presence of matrix components such as fibre or phosphates, leading to the formation of insoluble zinc complexes. It remains to be investigated to what extent this would affect IVS-solubility and bioavailability.

\section{Acknowledgements}

Financial support was provided by Wageningen University through the North-South Interdisciplinary Research and Education Fund (INREF). We gratefully acknowledge Dr. Cheng Suhong from Beijing Huateng Model Rice Mill Company (Beijing, China) who provided brown rice. We also gratefully acknowledge the assistance of $\mathrm{Lin} \mathrm{Li}$ and Jin Ying for mineral analysis.

\section{References}

Abdalla, A. A., El Tinay, A. H., Mohamed, B. E., \& Abdalla, A. H. (1998). Effect of traditional process on phytate and mineral content of pearl millet. Food Chemistry, 63, 79-84.

Andriotis, V. M. E., \& Ross, J. D. (2003). Isolation and characterisation of phytase from dormant Corylus avellana seeds. Phytochemistry, 64 , 689-699.

Badau, M. H., Nkama, I., \& Jideani, I. A. (2005). Phytic acid content and hydrochloric acid extractability of minerals in pearl millet as affected by germination time and cultivar. Food Chemistry, 92, 425-435.

Bentsink, L., Yuan, K., Koornneef, M., \& Vreugdenhil, D. (2003). The genetics of phytate and phosphate accumulation in seeds and leaves of Arabidopsis thaliana, using natural variation. Theoretical and Applied Genetics, 106, 1234-1243.

Capanzana, M. V., \& Buckle, K. A. (1997). Optimisation of germination conditions by response surface methodology of a high amylose rice (Oryza sativa) cultivar. Lebensmittel Wissenschaft und Technologie, 30, 155-163.

Carlson, D., \& Poulsen, H. D. (2003). Phytate degradation in soaked and fermented liquid feed-effect of diet, time of soaking, heat treatment, phytase activity, $\mathrm{pH}$ and temperature. Animal Feed Science and Technology, 103, 141-154.

Doesthale, Y. G., Devara, S., Rao, S., \& Belavady, B. (1979). Effect of milling on mineral and trace element composition of raw and parboiled rice. Journal of the Science of Food and Agriculture, 30, 40-46.

Fageer, A. S. M., Babiker, E. E., \& El Tinay, A. H. (2004). Effect of malt pretreatment and/or cooking on phytate and essential amino acid and in vitro protein digestibility of corn flour. Food Chemistry, 83, 261-265.
Gibson, R. S., Hotz, C., Temple, C., Yeudall, F., Mtitimuni, B., \& Ferguson, E. (2000). Dietary strategies to combat deficiencies of iron, zinc, and vitamin A in developing countries: Development, implementation, monitoring, and evaluation. Food and Nutrition Bulletin, 21, 219-231.

Heinemann, R. J. B., Fagundes, P. L., Pinto, E. A., Penteado, M. V. C., \& Lanfer-Marquez, U. M. (2005). Comparative study of nutrient composition of commercial brown, parboiled and milled rice from Brazil. Journal of Food Composition and Analysis, 18, 287-296.

Henderson, H. M., \& Ankrah, S. A. (1985). The relationship of endogenous phytase, phytic acid and moisture uptake with cooking time in Vicia faba minor cv. Aladin. Food Chemistry, 17, 1-11.

Hotz, C., Gibson, R. S., \& Temple, L. (2001). A home-based method to reduce phytate content and increase bioavailability in maize-based complementary diets. International Journal of Food Sciences and Nutrition, 52, 133-142.

Kennedy, G., Burlingame, B., \& Nguyen, N. (2002). Nutritional contribution of rice and impact of biotechnology and biodiversity in rice-consuming countries. In Proceedings of the 20th session of the international rice commission (pp. 59-69). Bangkok, Thailand: FAO.

Kiers, L. J., Nout, M. J. R., \& Rombouts, F. M. (2000). In vitro digestibility of processed and fermented soya bean, cowpea and maize. Journal of the Science of Food and Agriculture, 80, 1325-1331.

Larsson, M., Minekus, M., \& Havenaar, R. (1997). Estimation of the bioavailability of iron and phosphorus in cereals using a dynamic in vitro gastrointestinal model. Journal of Science of Food and Agriculture, 74, 99-106.

Larsson, M., \& Sandberg, A. S. (1995). Malting of oats in a pilot-plant process. Effects of heat treatment, storage and soaking conditions on phytate reduction. Journal of Cereal Science, 21, 87-95.

Leenhardt, F., Levrat Verny, M. A., Chanliaud, E., \& Remesy, C. (2005). Moderate decrease of $\mathrm{pH}$ by sourdough fermentation is sufficient to reduce phytate content of whole wheat flour through endogenous phytase activity. Journal of Agricultural and Food Chemistry, 53(1), 98-102.

Lestienne, I., Besançon, P., Caporiccio, B., Lullien-Pellerin, V., \& Trèche, S. (2005). Iron and zinc in vitro availability in pearl millet flours (Pennisetum glaucum) with varying phytate, tannin, and fiber contents. Journal of Agricultural and Food Chemistry, 53(8), 3240-3247.

Lestienne, I., Icard-Vernière, C., Mouquet, C., Picq, C., \& Trèche, S. (2005). Effects of soaking whole cereal and legume seeds on iron, zinc and phytate contents. Food Chemistry, 89(3), 421-425.

Lestienne, I., Mouquet-Rivier, C., Icard-Vernière, C., Rochette, I., \& Trèche, S. (2005). The effects of soaking of whole, dehulled and ground millet and soybean seeds on phytate degradation and Phy/Fe and Phy/ $\mathrm{Zn}$ molar ratios. International Journal of Food Science and Technology, 40(4), 391-399.

Liang, J., Han, B.-Z., Han, L., Nout, M. J. R., \& Hamer, R. J. (2007). Iron, zinc, and phytic acid content of selected rice varieties from China. Journal of the Science of Food and Agriculture, 87, 504-510.

Lopez, H. W., Duclos, V., Coudray, C., Krespine, V., Feillet-Coudray, C., Messager, A., et al. (2003). Making bread with sourdough improves mineral bioavailability from reconstituted whole wheat flour in rats. Nutrition, 19, 524-530.

Ma, G. (2007). Iron and zinc deficiencies in China: Existing problems and possible solutions. Ph.D. Thesis. Wageningen University, Wageningen.

Ma, G., Jin, Y., Piao, J., Kok, F., Bonnema, G., \& Jacobsen, E. (2005). Phytate, calcium, iron, and zinc contents and their molar ratios in food commonly consumed in China. Journal of Agricultural and Food Chemistry, 53, 10285-10290.

Mahgoub, S. E. O., \& Elhag, S. A. (1998). Effect of milling, soaking, malting, heat-treatment and fermentation on phytate level of four Sudanese sorghum cultivars. Food Chemistry, 61, 77-80.

Matuschek, E., Towo, E., \& Svanberg, U. (2001). Oxidation of polyphenols in phytate-reduced high-tannin cereals: Effect on different phenolic groups and on in vitro accessible iron. Journal of Agricultural and Food Chemistry, 49, 5630-5638. 
Nche, P. F., Odamtten, G. T., Nout, M. J. R., \& Rombouts, F. M. (1994). Dry milling and accelerated fermentation of maize for industrial production of kenkey, a Ghanaian cereal food. Journal of Cereal Science, 20, 291-298.

Reddy, N. R., \& Salunkhe, D. K. (1980). Effect of fermentation on phytate phosphorus and mineral content in black gram and rice. Journal of Food Science, 45, 1708-1712.

Sandberg, A.-S., Brune, M., Carlsson, N.-G., Hallberg, L., RossanderHulthen, L., \& Sandstrom, B. (1993). The effect of various inositol phosphates on iron and zinc absorption in humans. In U. Schlemmer (Ed.), Bioavailability '93: Nutritional, chemical and food processing implications of nutrient availability (Vol. 2, pp. 53-57). Berichte der Bundesforschungsanstalt für Ernährung BFE-R-93-01, Bundesforschungsanstalt für Ernährung, Karlsruhe, Germany, Ettlingen.

Sandberg, A. S., Brune, M., Carlsson, N. G., Hallberg, L., Skoglund, E., \& Rossander-Hulthen, L. (1999). Inositol phosphates with different numbers of phosphate groups influence iron absorption in humans. American Journal of Clinical Nutrition, 70, 240-246.

Towo, E., Matuschek, E., \& Svanberg, U. (2006). Fermentation and enzyme treatment of tannin sorghum gruels: Effect of phenolic compounds, phytate and in vitro accessible iron. Food Chemistry, 94, 369-376. 